\title{
Inhibitory influence of uterine secretions on mouse blastocysts decreases at the time of blastocyst activation
}

\author{
C. O’Neill* and P. Quinn†
}

Department of Biological Sciences, University of Newcastle, New South Wales 2308, Australia

\begin{abstract}
Summary. Uterine flushings from artificially 'pseudopregnant', pseudopregnant and pregnant mice and those with 'diapausing' embryos were tested for their effect on $\left[{ }^{3} \mathrm{H}\right]$ uridine incorporation by mouse blastocysts. An inhibitor of $\left[{ }^{3} \mathrm{H}\right]$ uridine incorporation was detected in the uterine fluid of the mice with diapausing embryos and the activity of the inhibitor was significantly reduced $6 \cdot 25 \mathrm{~h}$ after an injection of oestrogen. This reduction of the inhibitory activity was dependent on the presence of blastocysts in utero, since a similar reduction did not occur in uterine fluids of pseudopregnant mice. The results support the suggestion that 'delayed' implantation in mice is caused by the presence of inhibitors of blastocyst metabolism and that activation, after an increase in oestradiol, is due to an embryo-dependent loss of activity of the inhibitors.
\end{abstract}

\section{Introduction}

In mice and many other species of mammals, implantation of the blastocyst can be delayed. In this condition, both embryonic and uterine preparation for implantation are suspended for a period of time. It is generally acknowledged that embryonic 'diapause' in the mouse is the result of the absence of oestrogen secretion during the luteal phase (Finn \& Martin, 1974). Final uterine sensitization for implantation and blastocyst activation is triggered by an increased secretion of oestrogen (Humphrey, 1969). Blastocyst activation appears to be controlled by changes in the uterine environment (Aitken, 1977a, b). The manner by which the uterine environment exerts these effects is at present not known. It has been proposed that the uterine environment may act by containing an inhibitor of blastocyst metabolism which is negated by the 'nidatory' oestrogen secretion, or that blastocyst activation may result from the production of activating substances which are absent during embryonic 'diapause' (McLaren, 1973; Psychoyos, 1973).

Several studies provide support for putative uterine inhibitors of blastocyst function. Uterine flushings from mice at random stages of the oestrous cycle cause the inhibition of $\left[{ }^{3} \mathrm{H}\right] \mathrm{uridine}$ incorporation (O'Neill \& Quinn, 1981), as do flushings from artificially 'pseudopregnant' mice (Weitlauf, 1976, 1978). Psychoyos \& Casimiri (1981) have shown that rat and human uterine fluids, collected at periods refractory to implantation, are toxic to rat ova. Aitken $(1977 \mathrm{a}, \mathrm{b})$ has shown that uterine fluids from mice with diapausing embryos inhibit the hatching of blastocysts from the zona pellucida. The inhibitory effects in such uterine flushings have been shown to be dialysable, concentration-dependent and heat resistant. Further evidence for uterine inhibitors comes from transfer experiments which have shown that transfer of dormant embryos to ectopic sites such as

* Present address: Department of Veterinary Physiology, University of Sydney, New South Wales 2006. Australia.

† Present address: Department of Obstetrics and Gynaecology, Queen Elizabeth Hospital, Woodville, South Australia 5011. Australia. 
the kidney, anterior chamber of the eye (Kirby, 1969) and oviduct (Weitlauf, 1971) result in blastocyst activation. Bitton-Casimiri, Brun \& Psychoyos (1976) have found that transfer of delayed blastocysts to a simple culture medium results in an increase of metabolic activity.

The finding that actinomycin D could induce implantation in mice (Finn \& Downie, 1975) and rats (Camus, Lejeune \& Leroy, 1979) with experimentally 'delayed' blastocysts has added support for the role of putative intrauterine inhibitory factors of a protein nature. However, a widespread acceptance of the role of uterine inhibitory factors in embryonic 'diapause' has been prevented due to the inability to demonstrate the loss of the inhibitory influence of uterine flushings at the time of blastocyst activation (Weitlauf, 1976).

In the experimental design used by Weitlauf (1976) the donors providing uterine flushings had not in fact been mated but had had 'pseudopregnancy' induced artificially by the administration of gonadotrophins and steroid hormones. The use of such artificially 'pseudopregnant' mice to test for the differences in the effect of flushings from mice with diapausing embryos and those with normal times of implantation relies on the assumption that the embryo has a totally passive role during 'delayed implantation' and subsequent blastocyst activation. However, O'Neill \& Quinn (1981) have shown that the blastocyst is capable of negating the inhibitory effects of uterine flushings in vitro.

The present experiments compared the effect of flushings from artificially 'pseudopregnant', pseudopregnant and pregnant animals on the incorporation of $\left[{ }^{3} \mathrm{H}\right]$ uridine by blastocysts in vitro.

\section{Materials and Methods}

Embryos. All mice used were of the $\mathrm{F}_{1}$ hybrid cross $(\mathrm{C} 57 \mathrm{BL} \times \mathrm{CBA}$, or reciprocal) and were exposed to light from $07: 30$ to $21: 30 \mathrm{~h}$. Blastocysts were collected from 3-6-week-old females which had been induced to superovulate by intraperitoneal injection of 5-10 i.u. PMSG (Folligon: Intervet, Boxmeer, Holland) given at $15: 00-17: 00 \mathrm{~h}$, followed $46-50 \mathrm{~h}$ later by an injection of 5-10 i.u. hCG (Chorulon: Intervet). After the second injection, the females were placed with fertile males of the same $F_{1}$ hybrid type and checked the following morning for copulation plugs ( = Day 1 of pregnancy). Blastocysts were recovered between 12:00 and 15:00 h on Day 4 of pregnancy. The medium used for collection and culture of blastocysts was that of Whitten (Medium $\mathrm{W}_{1}$ ) prepared as indicated by Hoppe \& Pitts (1973).

Uterine fluids. Mature female mice were induced to ovulate by the administration of 5 i.u. PMSG and $\mathrm{hCG}$ as described above. The animals in Group A were not mated and were artificially 'pseudopregnant', those in Group B were pseudopregnant after mating with a vasectomized male and those in Group $\mathrm{C}$ were impregnated by fertile males.

The three groups of animals were bilaterally ovariectomized on the equivalent of Day 3 of pregnancy. The animals were injected with progesterone $(2 \mathrm{mg} / 0 \cdot 1 \mathrm{ml}$ peanut oil, s.c.) on Days 6 and 7. On Day 8 , the mice were injected s.c. with $0.2 \mathrm{mg}$ progesterone and $0.75 \mu \mathrm{g}$ oestradiol-17 $\beta$ to simulate the hormonal changes in delayed implantation (Days 6 and 7) followed by implantation (Day 8). Four mice from each treatment group were killed on Day 8 at 1, 2.5, 6.25 and $15.6 \mathrm{~h}$ after the progesterone and oestrogen injection.

A fourth group of animals (Group D) was induced to ovulate, mated with fertile males and bilaterally ovariectomized on Day 3. Embryonic 'diapause' was maintained up to Day 15 by a daily injection of $2 \mathrm{mg}$ progesterone. Uterine fluid was collected from these animals on Days 6, 9, 12 and 15 of pregnancy.

The uteri of all treated mice were removed and flushed with $50 \mu \mathrm{l}$ cold $\left(4^{\circ} \mathrm{C}\right)$ triple-distilled water, taking care not to introduce any contaminating fluid or cellular debris into the flushings, which were kept on ice during the collection period (Weitlauf, 1976). The flushing procedure was carried out in less than $2 \mathrm{sec}$ to minimize the effect of hypotonic shock to endometrial cells.

Fluid was pooled and centrifuged at $70000 \mathrm{~g}$ for $1 \mathrm{~h}$ at $4^{\circ} \mathrm{C}$. The supernatant was decanted and 
its protein concentration determined by the method of Lowry, Rosebrough, Farr \& Randall (1951). Samples of flushings containing $15 \mu \mathrm{g}$ protein were pipetted into sterile glass tubes and frozen at $-20^{\circ} \mathrm{C}$. The samples were then freeze-dried and stored at $-70^{\circ} \mathrm{C}$ until use. The flushings were prepared for culture by the addition of $75 \mu \mathrm{l} \mathrm{Medium} \mathrm{W}_{1}$ (containing $3 \mathrm{mg} \mathrm{BSA} / \mathrm{ml}$ ) to give a final concentration of $200 \mu \mathrm{g}$ uterine protein $/ \mathrm{ml}$.

Culture environment. Ten blastocysts were cultured in $10 \mu \mathrm{l}$ drops of medium under $10 \mathrm{ml}$ paraffin oil (Saybolt, Fisher Scientific Co., U.S.A.) in microtest plates (Falcon Plastics). The culture plates were incubated at $37^{\circ} \mathrm{C}$ in anaerobic gas jars that contained a humidified atmosphere of $5 \% \mathrm{O}_{2}: 5 \% \mathrm{CO}_{2}: 90 \% \mathrm{~N}_{2}$. Blastocysts were incubated in Medium $\mathrm{W}_{1}$ (control) or Medium $\mathrm{W}_{1}$ containing treatment flushings for $3 \mathrm{~h}$, followed by a $30 \mathrm{~min}$ incubation in Medium $\mathrm{W}_{1}$ containing $10 \mu \mathrm{M}-\left[5-{ }^{3} \mathrm{H}\right]$ uridine (sp. act. $28 \mathrm{Ci} / \mathrm{mmol}$ : Radiochemical Centre, Amersham, U.K.). Blastocysts were removed from the radioactive medium, washed three times ( $1 \mathrm{ml} /$ wash) in $\mathrm{Medium} \mathrm{W}_{1}$ containing $1 \mathrm{~mm}$ unlabelled uridine and stored at $-20^{\circ} \mathrm{C}$ for $1-3$ days until assayed.

Assessment of $\left[{ }^{3} \mathrm{H}\right]$ uridine incorporation. Samples were thawed and $0.2 \mathrm{ml}$ ice-cold mouse liver homogenate ( $4 \mathrm{ml} 0.25 \mathrm{M}$-sucrose containing $0.006 \mathrm{~N}-\mathrm{NaOH} / 1 \mathrm{~g}$ liver) was added to act as a carrier for labelled compounds. The acid-insoluble fraction was extracted with cold $20 \%$ trichloroacetic acid (TCA) for $30 \mathrm{~min}$. The precipitate was washed four times with $0.4 \mathrm{ml}$ cold $10 \%$ TCA. Further treatment with cold TCA did not reduce the amount of radioactivity and it is assumed that the acidinsoluble material contained the bulk of the radiolabelled RNA (Clegg \& Piko, 1977).

Statistical analysis. Each experiment was repeated three times and the values given in the text are means \pm s.e.m. Data were subjected to analysis of variance after logarithmic transformation. Differences between individual treatment means were tested by the Newman-Keuls multiple range test (Zar, 1974).

\section{Results}

After incubation for $3 \mathrm{~h}$ in Medium $\mathrm{W}_{1}$, blastocysts incorporated $12.32 \pm 1.03 \mathrm{fmol}\left[{ }^{3} \mathrm{H}\right]$ uridine in $30 \mathrm{~min}$. The results in Table 1 show that flushings collected from animals on Days 6, 9, 12 and 15 of pregnancy (Group C) resulted in a marked level of inhibition $\left(75-85 \%\right.$ ) of $\left[{ }^{3} \mathrm{H}\right]$ uridine incorporation.

As shown in Text-fig. 1, the incorporation of $\left[{ }^{3} \mathrm{H}\right]$ uridine by blastocysts in Medium $\mathrm{W}_{1}$ containing flushings from mice in Groups A and B was markedly inhibited. The time at which the flushings were collected after oestrogen injection did not result in a significant variation of their inhibitory effects. Flushings collected from pregnant animals (Group C) did show a timedependent reduction of the inhibitory effect. At 1 and $2.5 \mathrm{~h}$ the inhibitory effect was similar to that of flushings from mice in Groups $\mathrm{A}$ and $\mathrm{B}$, but at $6.25 \mathrm{~h}$ there was a marked reduction in the ability

Table 1. The inhibitory effect of uterine flushings taken from ovariectomized pregnant mice during progesterone-maintained 'delayed' implantation on the incorporation of $\left[{ }^{3} \mathrm{H}\right]$ uridine by mouse blastocysts

\begin{tabular}{cc}
\hline $\begin{array}{c}\text { Treatment } \\
\text { (day of pregnancy) }\end{array}$ & $\begin{array}{c}{\left[{ }^{3} \mathrm{H}\right] \text { Uridine incorporation }} \\
(\mathrm{fmol} / 30 \mathrm{~min} / \mathrm{embryo})^{*}\end{array}$ \\
\hline Medium W $_{1}$ (control) & $12.07 \pm 1.83$ \\
Day 6 & $3.19 \pm 0.69$ \\
Day 9 & $4.06 \pm 1.04$ \\
Day 12 & $3.73 \pm 1.21$ \\
Day 15 & $3.87 \pm 0.85$ \\
\hline
\end{tabular}

* Values are mean \pm s.e.m. for 3 replicates per treatment, 10 blastocysts per replicate. 


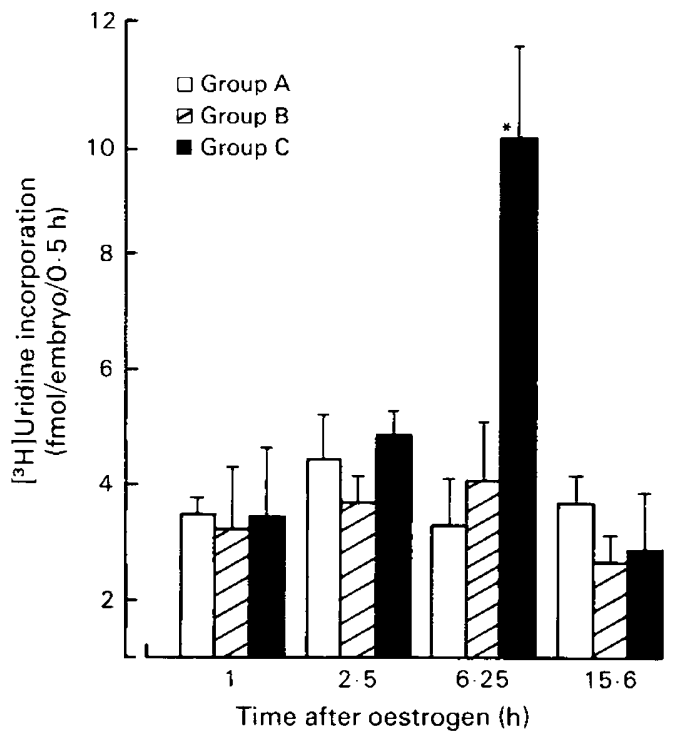

Text-fig. 1. The effect of incorporation of $\left[{ }^{3} \mathrm{H}\right]$ uridine by mouse blastocysts during culture in medium containing uterine flushings from artificially 'pseudopregnant' (Group A), pseudopregnant (Group B) and pregnant (Group C) mice, collected after an injection of 'nidatory' oestrogen. Each column represents the mean + s.e.m. of 3 replicates. ${ }^{*} P<0 \cdot 01$ compared with all other values.

to cause inhibition of uridine incorporation. By $15.6 \mathrm{~h}$, the inhibitory influence of the flushings was similar to that at 1 and $2 \cdot 5 \mathrm{~h}$.

\section{Discussion}

Our results confirm the findings of Weitlauf (1976) that uterine flushings from artificially "pseudopregnant' animals cause inhibition of $\left[{ }^{3} \mathrm{H}\right]$ uridine incorporation by blastocysts and that this inhibition is not lost after a 'nidatory' oestrogen injection. This work has been extended to show that uterine flushings from pseudopregnant mice exert the same influence as those from artificially 'pseudopregnant' mice, and that flushings from pregnant animals with embryonic 'diapause' also show a marked inhibition of $\left[{ }^{3} \mathrm{H}\right]$ uridine incorporation which is maintained for at least 12 days, i.e. to Day 15 after copulation. However, when an oestrogen injection was given to pregnant animals, the inhibitory effect of the flushings persisted for $2.5 \mathrm{~h}$ but was markedly reduced by $6.25 \mathrm{~h}$. This loss of inhibitory influence was temporary and by $15.6 \mathrm{~h}$ the inhibitory influence had returned to previous values.

The reduction of the inhibitory activity of flushings from pregnant mice occurs at a time when ultrastructural signs of blastocyst activation are apparent in vivo (Bergstrom \& Nilsson, 1975). The results give circumstantial support to the theory that the control of blastocyst activation in the mouse may be due to the presence of uterine inhibitors of embryonic metabolism during embryonic diapause which are negated at the time of blastocyst activation. The fact that the reduction of the inhibitory influence occurs in pregnant but not pseudopregnant mice, together with the evidence that blastocysts can neutralize the effect of the uterine inhibitor in vitro (O'Neill \& Quinn, 1981), suggests that the loss of the inhibitory effect in vivo is an embryo-dependent event. However, blastocysts are present in the uterus in normal and 'delayed' implantation, but diapausing blastocysts do not cause a loss of the inhibitory effect. This might be explained by one of two hypotheses. 
(1) The blastocyst could continue to neutralize the inhibitory activity during diapause but the secretion continues at concentrations compatible with embryonic dormancy. Following 'nidatory' oestrogen the secretion of the inhibitor is halted or decreases to such an extent that the embryodependent negation of the inhibitor becomes dominant, resulting in an effective reduction in concentration. (2) The response of the blastocyst could be different during 'delayed' and normal implantation such that the embryo-dependent negation of the inhibitory effect occurs only after the 'nidatory' oestrogen surge. Our results do not indicate which of these possibilities, if either, is involved.

It is also unclear how the embryo causes this loss of inhibitory activity. The embryo could act directly on the uterine secretion or indirectly via the endometrium to alter the nature of the secretions. There may be a decrease in the concentration of specific inhibitory factors or a fall in the activity of the factors without a change in the concentration. Such a change in activity might be achieved by a mechanism of the type proposed by Weitlauf (1976) whereby an inhibitor of the blastocyst inhibitor is produced. Circumstantial support for a change in the concentration of inhibitory factors may be provided by the findings of Aitken (1977c) that one serum and two minor non-serum proteins present in the first days of pregnancy and in experimental embryonic 'diapause', although not in 'diapause' induced by lactation, are not present at the time of blastocyst activation.

It is also possible, however, that the inhibitory activity in itself is not changed but that uterine fluids at the time of implantation contain factors which may stimulate the embryo to overcome the effects of the putative inhibitor. This proposal is supported by the fact that: (a) there are specific changes in protein secretion (serum and non-serum) into the uterine lumen following the 'nidatory' oestrogen peak (Aitken, 1977c; Pratt, 1977; Surani, 1977; Fishel, 1979); (b) this profile of uterine secretion is significantly greater in pregnant mice compared with pseudopregnant mice (Aitken 1977d), presumably representing an embryo-dependent event; and (c) blastocyst activation in vitro does not occur in simple defined medium but has a requirement for extracellular macromolecules (Fishel \& Surani, 1978). Nevertheless, blastocyst activation can be induced in animals undergoing delayed implantation by the injection of actinomycin D (Finn \& Downie, 1975; Camus et al., 1979) which significantly effects the characteristic profile of uterine protein secretion. The embryodependent loss of the inhibitory activity also occurs in vitro (O'Neill \& Quinn, 1981) which is a static system in which there is no increase in secretion of trophic factors. These arguments add support to the suggestion that the embryos act to cause a decrease in the activity of specific inhibitory factors. This does not rule out the possibility, however, that a concomitant rise in the activity of trophic factors may also occur.

As a working model, we propose that the uterine environment contains inhibitors of blastocyst metabolism throughout the preimplantation period of pregnancy and embryonic 'diapause'. Following the 'nidatory' oestrogen surge there is an embryo-dependent reduction of this inhibitory activity, allowing blastocyst activation to proceed. Blastocyst activation is likely to be promoted by one or more of the factors secreted into the uterine lumen.

\section{References}

Aitken, R.J. (1977a) The culture of mouse blastocyst in the presence of uterine flushings collected during normal pregnancy, delayed implantation and prooestrus. J. Embryol. exp. Morph. 41, 295-300.

Aitken, R.J. (1977b) Embryonic diapause. In Development of Mammals, Vol. 1, pp. 307-359. Ed. M. H. Johnson. North Holland Publishing Co., Amsterdam.

Aitken, R.J. (1977c) Changes in the protein content of mouse uterine flushings during normal pregnancy and delayed implantation, and after ovariectomy and oestradiol administration. J. Reprod. Fert. 50, 29-36.

Aitken, R.J. (1977d) The protein content of mouse uterine flushings during pseudopregnancy. $J$. Reprod. Fert. 50, 191-192.

Bergstrom, S. \& Nilsson, O. (1975) Embryo-endometrial relationship in the mouse during activation of the blastocyst by oestradiol. J. Reprod. Fert. 44, 117-120.

Bitton-Casimiri, V., Brun, J.L. \& Psychoyos, A. (1976) Uptake and incorporation of $\left[{ }^{3} \mathrm{H}\right]$ uridine by normal 
or diapausing rat blastocysts after various periods of culture. J. Reprod. Fert. 46, 447-448.

Camus, M., Lejeune, B. \& Leroy, F. (1979) Induction of implantation in the rat by intraparametrial injection of actinomycin D. Biol. Reprod. 20, 1115-1118.

Clegg, K.B. \& Piko, L. (1977) Size and specific activity of the UTP pool and overall rates of RNA synthesis in early mouse embryos. Devl Biol. 58, 76-95.

Finn, C.A. \& Downie, J.M. (1975) Changes in the endometrium of mice after the induction of implantation by actinomycin D. J. Endocr. 65, 259-264.

Finn, C.A. \& Martin, L. (1974) The control of implantation. J. Reprod. Fert. 39, 195-206.

Fishel, S.B. (1979) Analysis of mouse uterine proteins at pro-oestrus, during early pregnancy and after administration of exogenous steroids. J. Reprod. Fert. 55, 91-100.

Fishel, S.B. \& Surani, M.A.H. (1978) Changes in responsiveness of preimplantation mouse embryos to serum. J. Embryol. exp. Morph. 45, 295-301.

Hoppe, P.C. \& Pitts, S. (1973) Fertilization in vitro and development of mouse ova. Biol. Reprod. 8, 420-426.

Humphrey, K.W. (1969) Induction of implantation of blastocysts transferred to ovariectomized mice. $J$. Endocr. 44, 299-305.

Kirby, D.R.S. (1969) The extra-uterine mouse egg as an experimental model. $A d t$. Biosci. 4, 255-273.

Lowry, O.H., Rosebrough, N.J., Farr, A.L. \& Randall, R.J. (1951) Protein measurement with the Folin phenol reagent. J. biol. Chem. 193, 265-275.

McLaren, A. (1973) Blastocyst activation. In The Regulation of Mammalian Reproduction, pp. 321-328. Eds S. J. Segal, R. Crozier, P. A. Corfman \& P. G. Condliffe. C. C. Thomas, Springfield.
O'Neill, C. \& Quinn, P. (1981) Interactions of uterine flushings with mouse blastocysts in vitro as assessed by the incorporation of $\left[{ }^{3} \mathrm{H}\right]$ uridine. $J$. Reprod. Fert. 62, 257-262.

Pratt, H.P. (1977) Uterine proteins and the activation of embryos from mice during delayed implantation. $J$. Reprod. Fert. 50, 1-8.

Psychoyos, A. (1973) Endocrine control of egg implantation. In Handbook of Physiology, Section 7, Vol. 11, Part 2, pp. 201-256. Eds R. O. Greep \& E. B. Astwood. American Physiological Society, Washington, D.C.

Psychoyos, A. \& Casimiri, V. (1981) Uterine blastotoxic factors. In Cellular and Molecular Aspects of Implantation, pp. 327-340. Eds S. R. Glasser \& D. W. Bullock. Plenum, New York.

Surani, M.A.H. (1977) Qualitative and quantitative examinations of the proteins of uterine luminal fluid during pro-oestrus and pregnancy and comparison with those of serum. J. Reprod. Fert. 50, 281-287.

Weitlauf, H.M. (1971) Protein synthesis by blastocysts in the uteri and oviducts of intact and hypophysectomized mice. J. exp. Zool. 176, 35-40.

Weitlauf, H.M. (1976) Effect of uterine flushings on RNA synthesis by "implanting" and "delayed implanting" mouse blastocysts in vitro. Biol. Reprod. 14, 566-571.

Weitlauf, H.M. (1978) Factors in mouse uterine fluid that inhibit the incorporation of $\left[{ }^{3} \mathrm{H}\right]$ uridine by blastocysts in vitro. J. Reprod. Fert. 52, 321-325.

Zar, J.H. (1974) Biostatistical Analysis. Prentice-Hall, Inc., Englewood Cliffs.

Received 17 August 1982 